\title{
Use of lipid biomarkers for identification of regional sources and dechlorination characteristics of polychlorinated biphenyls in the East China Sea
}

\author{
Ying Fan ${ }^{a}$, Jing Lan ${ }^{\mathrm{b}}$, Huijuan $\mathrm{Li}^{\mathrm{a}, \mathrm{c}}$, Yali Cao ${ }^{\mathrm{a}}$, Zongshan Zhao ${ }^{\mathrm{a}, \mathrm{c}, *}$, Jiaokai Wang ${ }^{\mathrm{a}}$, Meixun Zhao ${ }^{\mathrm{a}}$, Guibin Jiang ${ }^{\mathrm{c}}$ \\ a Key Laboratory of Marine Chemistry Theory and Technology (Ocean University of China), Ministry of Education/Qingdao Collaborative Innovation Center of Marine Science and Technology, \\ Qingdao 266100, China \\ b College of Chemistry and Pharmaceutical Sciences, Qingdao Agricultural University, Qingdao 266109, China \\ c State Key Laboratory of Environmental Chemistry and Ecotoxicology, Research Center for Eco-Environmental Sciences, Chinese Academy of Sciences, P.0. Box 2871, Beijing 100085, China
}

\section{H I G H L I G H T S}

- Lipid biomarkers are introduced to study the environmental behaviors of PCBs.

- Regional sources of PCBs in the East China Sea sediments are different.

- Dechlorination of PCBs in the East China Sea sediments occurs in the hypoxic zone.

\section{A R T I C L E I N F O}

\section{Article history:}

Received 23 February 2014

Received in revised form 28 April 2014

Accepted 15 May 2014

Available online 5 June 2014

Editor: Adrian Covaci

\section{Keywords:}

Lipid biomarker

Polychlorinated biphenyls (PCBs)

Regional source

Dechlorination

East China Sea

\begin{abstract}
A B S T R A C T
Terrestrial organic matter (TOM) indicators could serve as proxies in studying the environmental behavior of organic pollutants because they are transported into the shelf seas along with the TOM. In this study, comparisons between polychlorinated biphenyls (PCBs) and TOM indicators of $\sum C_{27}+C_{29}+C_{31} n$-alkanes, as well as branched and isoprenoid tetraether (BIT) index, were performed to examine the regional sources of PCBs in the East China Sea. The results indicated that sedimentary PCBs in the mud area southwest of the Cheju Island, coastal area north of the $29^{\circ} \mathrm{N}$, and coastal area south of the $29^{\circ} \mathrm{N}$ were mainly from atmospheric deposition, riverine input of the Yangtze River, and local coastal sources via atmospheric deposition, respectively. The broad resemblance of the spatial patterns of non-definitive indicators of PCB dechlorination, hypoxia, and $\sum$ ladderane lipids suggested that deep dechlorination mainly occurred at the coastal areas and center shelf southwest of Cheju Island.
\end{abstract}

(C) 2014 Elsevier B.V. All rights reserved.

\section{Introduction}

Covering only $10 \%$ of the total seafloor, estuaries and shelf seas bury more than $90 \%$ of marine sedimentary organic matters (OMs) because of high terrestrial inputs and marine primary productivity (Hedges and Keil, 1995). High total organic carbon (TOC) content and sedimentation rate in the shelf seas could preserve organic pollutants (Arzayus

Abbreviations: BIT, branched and isoprenoid tetraether; ECS, East China Sea; KC, Kuroshio Current; MOM, marine organic matter; OHE, Old Huanghe Estuary; SPM, suspended particulate matter; TOC, total organic carbon; TOM, terrestrial organic matter; TWC, Taiwan Warm Current; YR, Yangtze River; YRE, Yangtze River Estuary; YSCC, Yellow Sea Coastal Current; ZFCC, Zhejiang-Fujian Coastal Current.

* Corresponding author at: Room 2-303, College of Chemistry and Chemical Engineering, Ocean University of China, 238 Songling Road, Qingdao 266100, China. Tel.: +865326678 2170; fax: +8653266782103.

E-mail addresses: zhaozongshan@ouc.edu.cn, zhaozs@qibebt.ac.cn (Z. Zhao). et al., 2001; Mai et al., 2002). Moreover, shelf seas have been considered as important reservoirs of anthropogenic organic contaminants. In the past few decades, numerous persistent organic pollutants (POPs) have been transported and buried in these regions, which are heavily affected by humans through surface runoffs and atmospheric deposition (Arzayus et al., 2001; Jönsson et al., 2003; Wafo et al., 2006).

Sedimentary OMs in estuaries and their surrounding regions mainly consist of marine organic matter (MOM) and terrestrial organic matter (TOM) (Hedges and Keil, 1995). Recently, some lipid compounds derived from plants, bacteria, or archaea, such as long-chain odd-carbon $n$-alkanes, long-chain even-carbon $n$-alkanols, and fatty acids, have been proposed as useful biomarkers for evaluating TOM contributions on sedimentary OM (Amo and Minagawa, 2003; Xing et al., 2011a, 2011b; Zhao et al., 2000). Brassicasterol, dinosterol, and $C_{37}$ alkenones produced by marine algae are reliable MOM indicators. In addition, the content ratios of $n$-alkanes to algal biomarkers can be used to 
estimate the relative contribution of TOM in marine environments (Amo and Minagawa, 2003; Xing et al., 2011b).

Previous reports have indicated that $n$-alkanes could enter oceans through fluvial and atmospheric inputs (Bird et al., 1995; Gagosian et al., 1981; Simoneit et al., 1977). Branched glycerol dialkyl glycerol tetraethers (GDGTs) in marine sediments are mainly from river inputs (Hopmans et al., 2004). Branched and isoprenoid tetraether (BIT) index, which is the relative abundance of branched GDGTs over crenarchaeol (Sinninghe Damsté et al., 2002), can reflect the fluvial TOM entering into marine environments through surface runoffs (Hopmans et al., 2004). Comparable distribution characteristics are expected to improve the identification of POP sources because TOM and POPs are from land (Zhao et al., 2013b).

In a recent study, ladderane lipids, which are unique membrane lipids of anammox bacteria and prevalent within oxygen minimum zone, have been found to be potential biomarkers for indicating anammox in marine sediments (Jaeschke et al., 2009a) and anaerobic water columns (Kuypers et al., 2003). The correlation between ladderane lipids and sediment/water depth of minimum oxygen zones suggests the limiting effects of oxygen on anammox (Jaeschke et al., 2007, 2009b). We proved in our previous study that ladderane lipids could be indicative of hypoxia (Zhao et al., 2013a). Therefore, the introduction of ladderane lipids is beneficial in the evaluation of the environment fates of POPs.

Polychlorinated biphenyls (PCBs) are one of the priority POPs because of their global distribution, food web bioaccumulation, and potential adverse effects on humans (Jones and de Voogt, 1999; Safe, 1993). PCB occurrence and distribution in Chinese marginal sea have been a concern in recent years. Congener compositions, geographical characteristic, TOC, and grain size have been used to investigate their distribution characteristics and sources (Duan et al., 2013; Gao et al., 2013; Yang et al., 2011,2012). Studies have shown that PCBs are transferred into the East China Sea (ECS) mainly via surface runoff, industrial wastewater, and atmospheric deposition. However, reports on PCB sources are still preliminary and limited, especially in the sea shelf area, because they cannot specifically reflect the regional sources of PCBs. Furthermore, the fate of PCBs has not been elucidated because of lack of comparable data for environment factors.

In the present study, PCBs and biomarkers of $C_{27}+C_{29}+C_{31} n$ alkanes, branched GDGTs, crenarchaeol, and ladderane fatty acids in the surface sediments of the ECS were studied. The regional sources and dechlorination behavior of PCBs in the ECS were investigated, and the utilization of lipid biomarkers in studying anthropogenic contaminants was further explored (Dachs et al., 1999; Salau et al., 1997).

\section{Materials and methods}

\subsection{Sample collection}

ECS is one of the largest shelf seas in the world and an important terrestrial matter sink in China. The Yangtze River (YR) is the dominant surface runoff and source of sediments of the ECS. It discharges into the ECS approximately $0.5 \times 10^{15} \mathrm{~g} \mathrm{yr}^{-1}$ of terrestrial particulate matters annually (Wang et al., 2008), with approximately $12 \times 10^{12} \mathrm{~g} \mathrm{yr}^{-1}$ of OM (Wu et al., 2003). In addition, the Qiantang River, Ou River, and Min River may have local or even regional importance, despite their considerably lower contributions ( $<4 \%$ of YR) on the terrestrial matters entering the ECS (Liu et al., 2007). The main tidal currents affecting the sediment dispersal in ECS are shown in Fig. 1. These currents include the Zhejiang-Fujian Coastal Current (ZFCC), Taiwan Warm Current (TWC), Yellow Sea Coastal Current (YSCC), and Kuroshio Current (KC). Most of Yangtze-derived sediments are transported southwards along the coast by the ZFCC and trapped in the inner shelf as blocked by the TWC and $\mathrm{KC}$, forming an elongated Zhejiang-Fujian mud wedge from the Yangtze mouth into the Taiwan Strait (Liu et al., 2007). The YSCC has a key role in transporting sediments from the Old Huanghe Estuary (OHE) to the mud area southwest off the Cheju Island (Milliman et al., 1989).
In the past decades, intensified anthropogenic activities and population growth in the YR drainage basin and coastal areas have significantly affected the eco-environment of the ECS. Significant amounts of land-derived organic pollutants, such as polycyclic aromatic hydrocarbons (PAHs) (Hung et al., 2011), organochlorine pesticides (OCPs) (Lin et al., 2012), polybrominated diphenyl ethers (PBDEs) (Chen et al., 2006), and short-chain chlorinated paraffins ( $\mathrm{C}_{10}-\mathrm{C}_{13}$, SCCPs) (Zhao et al., 2013b), have been released into the ECS in various ways. In this study, 43 surface sediment samples $(0 \mathrm{~cm}$ to $3 \mathrm{~cm})$ were collected along nine inshore-offshore transects of the ECS (DH1 to DH8, HE) during the cruise in June 2011 (Fig. 1), using a multiple corer deployed from the R/V of Beidou of the Yellow Sea Fisheries Research Institute. All samples were then freeze-dried, homogenized, and stored at $-20{ }^{\circ} \mathrm{C}$ until analysis.

\subsection{Extraction and clean-up}

Approximately $5.0 \mathrm{~g}$ sediment sample was spiked with ${ }^{13} \mathrm{C}$-labeled PCB surrogate standards (EPA 68A-LCS, Wellington Laboratories, Canada) and extracted using an accelerated solvent extraction (ASE300, Dionex, USA) with a solvent mixture of dichloromethane/n-hexane $(1: 1, v / v)$. Then, activated copper powder was added to remove sulfur. After distilling in a rotary evaporation, the extract was cleaned using a multilayer silica column filled with $1 \mathrm{~g}$ silica, $4 \mathrm{~g}$ basic silica $(1.2 \%, w / w)$, $1 \mathrm{~g}$ silica, $8 \mathrm{~g}$ acidic silica $(30 \%, w / w), 2 \mathrm{~g}$ silica, and $4 \mathrm{~g}$ anhydrous sodium sulfate from bottom to top, and prewashed with $80 \mathrm{~mL} n$-hexane. The extract solution was then eluted with $100 \mathrm{~mL} n$-hexane and was subsequently concentrated to a final volume of $20 \mu \mathrm{L}$. Prior to instrumental analysis, ${ }^{13} \mathrm{C}$-labeled PCBs (EPA 68A-IS) were added as internal standards to determine the recoveries of the labeled surrogate standards.

For $n$-alkanes analysis, approximately $2.0 \mathrm{~g}$ of sediment sample, which was spiked with an internal standard mixture containing $C_{19} n$ alkanol and $\mathrm{C}_{24}$ deuterium-substituted $n$-alkane, was extracted for 15 min with dichloromethane/methanol $(3: 1, v / v)$ using ultrasonication. This extraction procedure was repeated four times. The combined extracts were first hydrolyzed with $6 \% \mathrm{KOH}$ in methanol, extracted with $n$-hexane, and then cleaned using a silica gel column. The nonpolar lipid fraction, eluted from the column with $8 \mathrm{~mL} n$-hexane, was dried under a gentle nitrogen stream for instrumental analysis.

For the branched GDGTs and crenarchaeol, approximately $5.0 \mathrm{~g}$ sediment sample, which was spiked with $\mathrm{C}_{46} \mathrm{GDGT}$ internal standard, was extracted with $10 \mathrm{~mL}$ methanol in an ultrasonic bath for $15 \mathrm{~min}$. Then, the extract was transferred into clean vials after centrifugation at $3000 \mathrm{rpm}$ for $3 \mathrm{~min}$. The extraction procedure was repeated twice. Afterward, the sample was sequentially extracted with methanol/ dichloromethane $(1: 1, v / v)$ and dichloromethane using ultrasonication. Each extraction was also repeated twice. The combined extracts were concentrated under a gentle nitrogen steam and processed through a small anhydrous sodium sulfate column to remove excess water. The solution was concentrated and further cleaned using an alumina column. Dichloromethane $/ n$-hexane ( $8 \mathrm{~mL}, 1: 9, v / v$ ) was added to elute the non-polar lipid fraction. The polar fraction, eluted with $12 \mathrm{~mL}$ methanol/dichloromethane $(1: 1, v / v)$, was concentrated and subsequently filtered for instrumental analysis.

For ladderane lipids, $10.0 \mathrm{~g}$ sediments were extracted four times using ultrasonication with $15 \mathrm{~mL}$ dichloromethane/methanol $(2: 1, v / v)$. The combined extracts were treated with activated copper powder overnight to remove sulfur. The supernatant was then saponified with $1 \mathrm{~mol} / \mathrm{L} \mathrm{KOH}$ in methanol overnight. After saponification, $n$ hexane was used to extract the neutral components from the basic solution $(\mathrm{pH}>13)$ for four times. The remaining solution was acidified to $\mathrm{pH}=3$ and subsequently extracted with $n$-hexane for four times to obtain acidic components. Both neutral and acidic components were dried over a small anhydrous sodium sulfate column. Acidic ladderane components were converted to their corresponding methyl esters (FAMEs) using a $\mathrm{BF}_{3} /$ methanol (20\%) solution. All obtained ladderane 


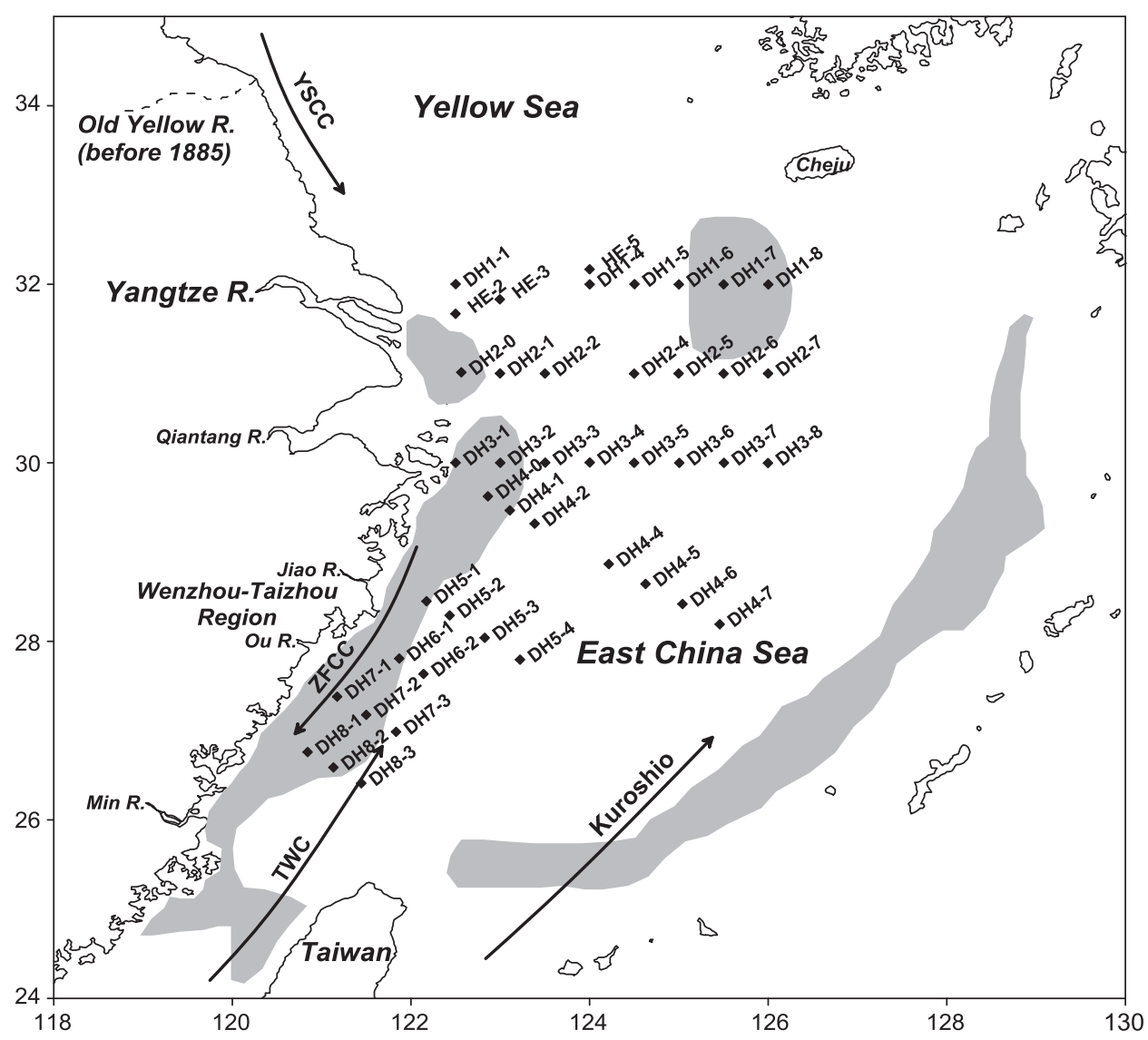

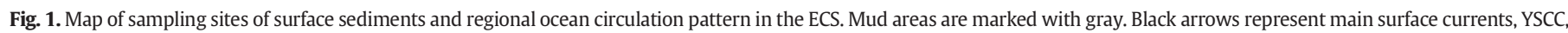
ZFCC, TWC, and Kuroshio.

lipids were dissolved in methanol, followed by filtration through a PTFE filter $(0.45 \mu \mathrm{m}, 4 \mathrm{~mm}$ in diameter), and then spiked with an internal standard of 2-hydroxy-4-methoxy benzophenone prior to the instrumental analysis.

\subsection{Instrumental analysis}

A total of 25 PCBs, including 12 dioxin-like congeners (PCB-77, 81, $105,114,118,123,126,156,157,167,169$, and 189), six indicator congeners (PCB-28, 52, 101, 138, 153, and 180), and seven other congeners (PCB-3, 15, 19, 202, 205, 208, and 209), were analyzed using an Agilent $6890 \mathrm{~N}$ high-resolution gas chromatography system (Wilmington, USA) with a CTC PAL autosampler connected to the AutoSpec Ultima highresolution mass spectrometer (HRMS) (Waters Micromass, UK) with an electron impact (EI) ion source. A DB-5 fused silica capillary column ( $0.25 \mu \mathrm{m}$ film thickness, $60 \mathrm{~m} \times 0.25 \mathrm{~mm}$ i.d.; J\&W Scientific, Folsom, CA, USA) was used for the chromatographic separation. The HRMS was operated in VSIR mode at $R \geq 10,000$, and the source temperature was $270{ }^{\circ} \mathrm{C}$. The electron emission energy was set to $35 \mathrm{eV}$. Helium was used as the carrier gas at a constant flow rate of $1.0 \mathrm{~mL} / \mathrm{min}$. The initial oven temperature was held at $80{ }^{\circ} \mathrm{C}$ for $3 \mathrm{~min}$, increased to $150{ }^{\circ} \mathrm{C}$ at $15^{\circ} \mathrm{C} / \mathrm{min}$, and then held for 2 min followed by increasing to $270{ }^{\circ} \mathrm{C}$ at $2.5^{\circ} \mathrm{C} / \mathrm{min}$ and holding for $3 \mathrm{~min}$. Finally, the temperature was raised to $330{ }^{\circ} \mathrm{C}$ at $15{ }^{\circ} \mathrm{C} / \mathrm{min}$ and maintained for $13 \mathrm{~min}$. PCBs were quantified using isotope-dilution method.

n-Alkanes were quantified using an Agilent 6890N GC coupled with an FID detector. An HP-1 capillary column $(50 \mathrm{~m} \times 0.32 \mathrm{~mm}$ i.d., $0.17 \mathrm{~mm}$ film thickness; J\&W Scientific) was used for chromatographic separation. Hydrogen was used as the carrier gas at a constant flow rate of $1.2 \mathrm{~mL} / \mathrm{min}$. The oven temperature program was started by increasing the temperature from $80{ }^{\circ} \mathrm{C}$ to $200{ }^{\circ} \mathrm{C}$ at $25^{\circ} \mathrm{C} / \mathrm{min}$ and then to
$250{ }^{\circ} \mathrm{C}$ at $4{ }^{\circ} \mathrm{C} / \mathrm{min}$. The temperature was further increased to $300{ }^{\circ} \mathrm{C}$ at $1.8^{\circ} \mathrm{C} / \mathrm{min}$ and was finally held at that temperature for $15 \mathrm{~min}$. Identification was performed by comparing the retention times of the standards using a Thermo GC coupled with a MS detector (Finnigan Trace DSQ), which was operated in the electron ionization (EI) mode. The EI energy was $70 \mathrm{eV}$, and the mass scanning ranged between $\mathrm{m} / \mathrm{z}$ 50 and 650 amu. An EQUITYTM -5 Capillary Column $(30 \mathrm{~m} \times 0.25 \mathrm{~mm}$ i.d., $0.25 \mathrm{~mm}$ film thickness) was used, and helium was used as the carrier gas. The temperature program was started by increasing the temperature from $60{ }^{\circ} \mathrm{C}$ to $200{ }^{\circ} \mathrm{C}$ at $15^{\circ} \mathrm{C} / \mathrm{min}$ and then to $300{ }^{\circ} \mathrm{C}$ at $2.5^{\circ} \mathrm{C} / \mathrm{min}$, which was held for $5 \mathrm{~min}$.

The branched GDGTs, crenarchaeol, and ladderane lipids were analyzed using an Agilent 1200 Series high performance liquid chromatography system (Agilent Technologies, Palo Alto, CA) coupled with a Waters-Quattro Ultima MS system (Waters Corp., New Jersey, US). The branched GDGTs and crenarchaeol were separated using a Prevail Cyano column $(150 \mathrm{~mm} \times 2.1 \mathrm{~mm})$ with the flow rate of $0.2 \mathrm{~mL} / \mathrm{min}$ at $30{ }^{\circ} \mathrm{C}$. $n$-Hexane (Solvent A) and isopropanol (Solvent B) were used as mobile phase with a gradient elution of $A: B$ from 99:1 (held for $5 \mathrm{~min}$ ) to $98.2: 1.8$ in $45 \mathrm{~min}$. Atmospheric pressure chemical ionization (APCI) source was used to perform mass spectrometric detection in the single ion monitoring mode, and the dwell time was $100 \mathrm{~ms}$. The identified ions were $[\mathrm{M}+\mathrm{H}]^{+}$with $m / z$ of 1292 for crenarchaeol, 1050, 1036, and 1022 for branched GDGTs, and 744 for $\mathrm{C}_{46} \mathrm{GDGT}$. The source temperature and APCI probe temperature were 95 and $550{ }^{\circ} \mathrm{C}$, respectively. The nebulizer pressure and temperature were set to $60 \mathrm{psi}$ and $400{ }^{\circ} \mathrm{C}$, respectively. Nitrogen was used as the nebulizer gas at a flow rate of $600 \mathrm{~L} / \mathrm{h}$, and the gas flow rate of the cone was set to $80 \mathrm{~L} / \mathrm{h}$. For ladderane lipids, a Zorbax Eclipse XDB- $C_{8}$ column $(3.0 \mathrm{~mm} \times 250 \mathrm{~mm}$, $5 \mu \mathrm{m}$; Agilent) was used to achieve chromatographic separation at $30{ }^{\circ} \mathrm{C}$. Ladderane lipids were eluted with methanol at a flow rate of 
$0.3 \mathrm{~mL} / \mathrm{min}$ for $20 \mathrm{~min}$. APCI source was used to perform mass spectrometric detection in a selected ion recording mode. The identified ions of ladderane FAMEs were $\left[\mathrm{M}+\mathrm{H}^{+}\right.$with $m / z$ of 289,317 , and 319 for $\mathrm{C}_{18}$-[5]-ladderane FAME (I), $\mathrm{C}_{20}$-[5]-ladderane FAME (III), and $\mathrm{C}_{20}$-[3]-ladderane FAME (IV), respectively. The temperatures of the source and APCI probe were set to $120{ }^{\circ} \mathrm{C}$ and $550{ }^{\circ} \mathrm{C}$, respectively. The corona voltage was 3.0 $\mu \mathrm{A}$. Nitrogen was used as the cone gas at a flow rate of $120 \mathrm{~L} / \mathrm{h}$, and the desolvation gas at a flow rate of $350 \mathrm{~L} / \mathrm{h}$.

\subsection{Quality assurance and quality control}

All solvents used were of pesticide grade. All glassware was rinsed with DCM and $n$-hexane to prevent contamination in the PCB analysis. For each batch (12 samples), a laboratory blank (anhydrous sodium sulfate) was added, and PCB-28 was the predominant blank contaminant (Table S1). All samples were blank corrected. The method limits of detection ranged from $0.023 \mathrm{pg} / \mathrm{g}$ to $0.163 \mathrm{pg} / \mathrm{g}$. The average recoveries of the surrogate PCBs ranged from $37.5 \%$ to $137 \%$ (Table S2).

\section{Results and discussion}

\subsection{Occurrence of PCBs}

PCBs were detected in all 43 samples from the coast to the middle shelf of the ECS, indicating their widespread distribution. The PCB congeners in the sediments included 12 dioxin-like PCBs (CB-77, 81, 105, $114,118,123,126,156,157,167,169$, and 189), six indicator congeners (CB-28, 52, 101, 138, 153, and 180), and six other congeners (CB-3, 15, $202,205,208$, and 209) (Table S3). The total contents of the 24 PCB congeners in these samples are listed in Table S4. The total PCB contents ( $\sum_{24} \mathrm{PCBs}$, sum contents of all 24 congeners) ranged from $19.08 \mathrm{pg} / \mathrm{g}$ dw to $496.01 \mathrm{pg} / \mathrm{g} \mathrm{dw}$, with an average value of $125.41 \mathrm{pg} / \mathrm{g} \mathrm{dw}$. The PCB levels were comparable with the sediments from the Yangtze River Estuary (YRE) and ECS inner shelf (24.3 pg/g to $343.3 \mathrm{pg} / \mathrm{g}$ ) (Duan et al., 2013), but were markedly lower than those detected in the surface sediments of Bohai Bay (n.d. to 36,100 pg/g) (Zhao et al., 2010), southern Yellow Sea (518 pg/g to $5848 \mathrm{pg} / \mathrm{g}$ ) (Zhang et al., 2007), and Pearl River estuary (11.13 ng/g to $23.23 \mathrm{ng} / \mathrm{g}$ ) (Nie et al., 2005) in China. Their values were in the low end of the global content range of PCBs $(0.2 \mathrm{ng} / \mathrm{g}$ to $400 \mathrm{ng} / \mathrm{g})$ in nearshore surface sediments (Fowler, 1990). Light congeners, including mono-, di-, tri-, and tetra-PCBs, accounted for $46.0 \%$ to $93.1 \%$ (average value of $70.6 \%$ ) of the total PCBs, and the percentage of medium (penta-, hexa-, and hepta-PCBs) and heavy (octa-, nona-, and deca-PCBs) congeners ranged from $4.8 \%$ to $49.2 \%$ (average value of $24.9 \%$ ) and $1.3 \%$ to $10.5 \%$ (average value of $4.5 \%$ ), respectively (Fig. S1). The dominant PCBs had low chlorination levels of congeners in the surface sediments of ECS and Bohai Bay (Gao et al., 2013; Yang et al., 2012; Zhao et al., 2010).

\subsection{Spatial distribution of PCBs and TOC}

PCBs ( $\left.\sum_{24} \mathrm{PCBs}\right)$ in the ECS had two distinct spatial distribution features, namely, a decrease from inshore to offshore and an increase from north to south (Fig. 2a). Most sites with high $\sum_{24} \mathrm{PCBs}$ were located in the mud area along the Zhejiang-Fujian coastline. The spatial pattern was similar to some other anthropogenic contaminants, including PAHs (Lü and Zhai, 2005), SCCPs (Zhao et al., 2013b), and OCPs (Yang et al., 2005) in this region. The seaward decreasing trend indicated the direct impact of land-derived sources of the coastal area. The northsouth increasing trend in the inner shelf corresponded to the southward flow direction of ZFCC and to the mud belt deposited southward from the Yangtze mouth along the Zhejiang-Fujian coastline, which is the deposition center of terrigenous matters from YR since Holocene (Liu et al., 2007) (Fig. 1). These results suggested that the distribution of PCBs may be controlled by the input of YR and transport of ZFCC. The contribution of local rivers was limited because all sampling sites were relatively far from the coastline (Fig. 1), and about $83 \%$ to $85 \%$ of the sedimentary matters in the inner shelf were from YR (Xiao et al., 2005). The southern inner shelf with the highest PCB content is adjacent to the TaizhouWenzhou Region, which is a significant e-waste dismantling area in China with fairly high levels of atmospheric PCBs (Han et al., 2010). The prevailing northwest and east-southeast wind (Fig. 1d) facilitates the transport of PCBs into the downwind marine environment. Hence, most of the sedimentary PCBs in the inner shelf were speculated to originate from the river input of YR and atmospheric deposition.

The river-sea boundary zone is widely considered as the accumulation area of pollutants because of its proximity to the emission source and "marginal filter" (Dahle et al., 2003; Yang et al., 2012). However, relatively lower levels of $\sum_{24} \mathrm{PCBs}$ were observed in the HE-2 site near the YRE, which is consistent with a previous report by Gao et al. (2013) in 2010 and 2011. This phenomenon could be explained by the intrusion of seawater with low levels of PCBs (Gao et al., 2013), despite the intensified flocculation and gravitational sedimentation of suspended particulate matter (SPM) in the river-sea boundary zone (Dahle et al., 2003). Moreover, intensified hydrodynamic conditions are not conducive to the deposition of smaller SPM adsorbing more organic pollutants.

In the mud area southwest of Cheju Island, the high $\sum_{24} \mathrm{PCBs}$ dominated by low-chlorinated PCBs (Fig. 2a and Table S4) suggested that the mud area is a significant sink of PCBs, such as several other contaminants of PAHs (Guo et al., 2006), heavy metals (Zhang et al., 1992), and SCCPs (Zeng et al., 2012). Southwest of Cheju Island is a modern depositional center of the ECS (DeMaster et al., 1985), and the sediments mainly originated from OHE in northern Jiangsu Province (Milliman et al., 1989). Only a few pollutants are involved in these sediments from OHE (Guo et al., 2001). The pollutants from East Asia can be transported to the northern Pacific Ocean by the East Asian monsoon (Wilkening et al., 2000). Hence, the northern ECS is located downwind of North China and the pathway for terrestrial pollutants to the northern Pacific, resulting in many pollutants entering the northern ECS through atmospheric deposition (Guo et al., 2003; Zhang et al., 1992). The lighter PCBs are more prone to accumulate in the atmosphere and be transported farther from the source compared with the heavy congeners. Additionally, primary productivity has been found to modulate the deposition of atmospheric PCBs in marine environments driven by biological pump (Dachs et al., 2002; Galbán-Malagón et al., 2012). Hence, high low-chlorinated PCBs (mono- to tetra-PCBs) corresponding to high primary productivity (Kim et al., 2009) in this region indicated that most of these sedimentary PCBs could be attributed to atmospheric transportation from North China.

Sedimentary TOC content is a significant factor controlling the distribution of organic contaminants because of the affinity of these compounds with particle matters (Arzayus et al., 2001; Maruya et al., 1996; Yang et al., 2005; Zhang et al., 2007; Zhao et al., 2013b). In the present study, the TOC content (wt.\%) ranged from $0.12 \%$ to $0.71 \%$ (Table S4), with a mean value of $0.32 \%$, which is slightly lower than those from the ECS surface sediments in 2007 (Lin et al., 2012). Moreover, the distribution pattern of TOC contents resembled that of the $\sum_{24}$ PCBs (Fig. 2b). Significant relation $(r=0.73, p<0.05)$ was observed between the TOC and $\sum_{24} \mathrm{PCBs}$, in agreement with those of Yueqing Bay, Xiangshan Bay, and Sanmen Bay of ECS (Yang et al., 2011), implying that PCB distribution may be controlled by their absorption on particulate organic carbon (Lin et al., 2012). Mineral grain size (content percentage of sand) analysis showed that the inner shelf (10\% to $30 \%$ ) was composed mostly of fine terrestrial matters, and the middle-outer shelf (>30\%) was composed of coarse-grained quartz and some biogenic carbonates (Lin et al., 2002). The correlation between high $\sum_{24} \mathrm{PCBs}$ and fine particles indicated that the deposition of PCBs is also heavily affected by grain size (Duan et al., 2013; Piérard et al., 1996).

In a site locating far from land, TOC-normalized concentrations of POPs decrease at high organic carbon contents and fluxes because the atmospheric inputs of POPs cannot compensate the sinking fluxes of 

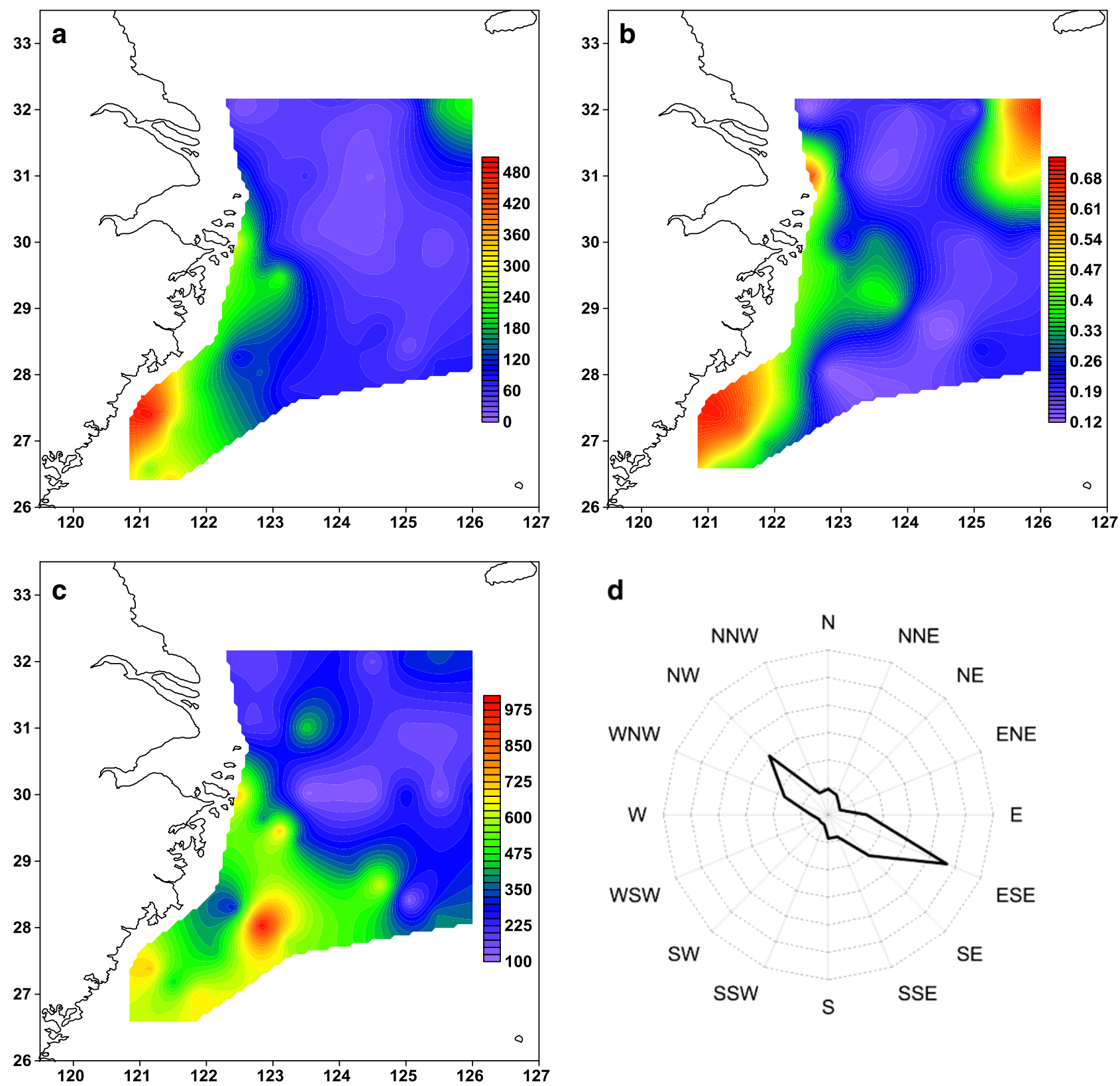

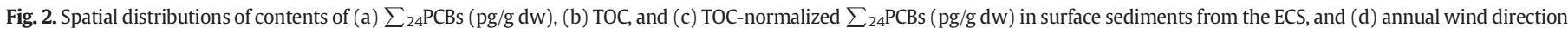
statistics of the Taizhou-Wenzhou region.

organic carbon (Dachs et al. 2000, 2002). The spatial distribution of TOC-normalized $\sum_{24} \mathrm{PCB}$ concentrations presented a distinct increasing trend from the northern ECS to the southern ECS (Fig. 2c). Compared with the spatial distribution of $\sum_{24} \mathrm{PCBs}$, such distinct distribution characteristics suggest that PCBs in the mud area southwest of Cheju Island are from atmospheric deposition mediated by biological pump (Dachs et al., 2002; Galbán-Malagón et al., 2012). Moreover, PCBs in the southern ECS may be attributed to both river input and atmospheric deposition.

\subsection{Congener pattern of PCBs}

The spatial distributions of congener groups of PCBs are shown in Fig. 3, which presents a significant variation according to the different degrees of chlorination. Light congeners (mono- to tetra-PCBs) (Fig. 3a) showed a similar pattern with $\sum{ }_{24} \mathrm{PCBs}$ (Fig. 2a), with the high value areas located in the mud areas along the Zhejiang-Fujian coastline and southwest of Cheju Island. This resemblance could be attributed to their dominance in the sedimentary PCBs. High contents of medium and heavy PCBs were observed at sites located in the area along the Zhejiang-Fujian coastline south of the $29^{\circ} \mathrm{N}$ (Fig. 3b and c). Given that highly chlorinated PCBs with a high $K_{\mathrm{ow}}$ are more likely to be adsorbed on SPM, these PCBs are expected to accumulate in sediments closer to the source compared with low-chlorinated PCBs. Therefore, the accumulation of heavier PCBs in the inner shelf (south of the $29^{\circ} \mathrm{N}$ ) demonstrated that these PCBs are mainly from local sources.

Recent studies have shown that the usage of older PCB-containing electrical equipment (Fu et al., 2003) and disordered release of electronic waste (e-waste) recycling industries (Wong et al., 2007) are the major contributors to PCBs in the ECS because PCB production ceased in 1983. The Taizhou-Wenzhou region, which is one of the largest ewaste recycling centers in China, is exactly located in the upwind area of the sea region (south of the $29^{\circ} \mathrm{N}$; Fig. 1). Penta- and hexa-PCBs have been reported as the dominant congeners (33.8\% and $32.1 \%$, 

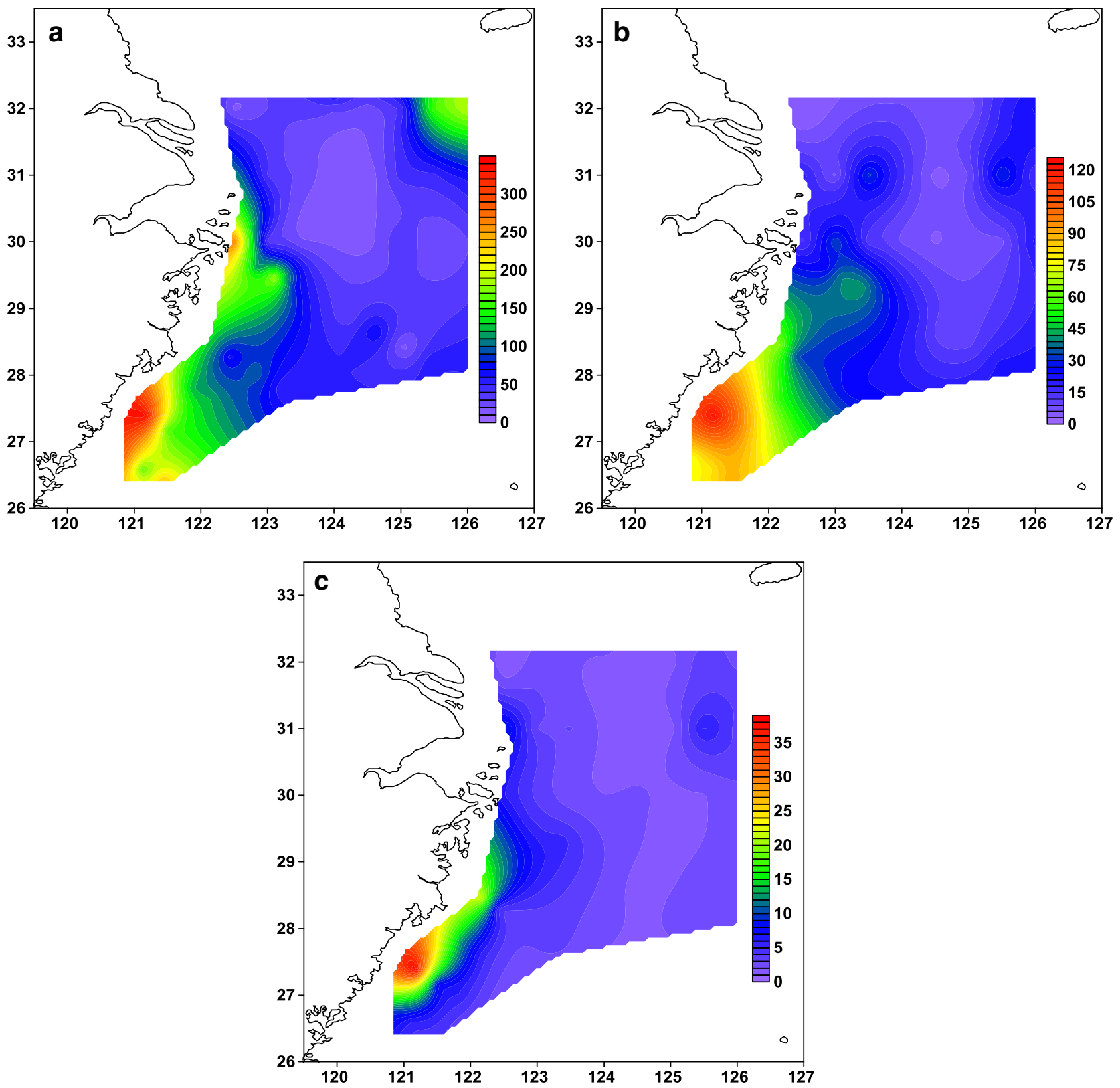

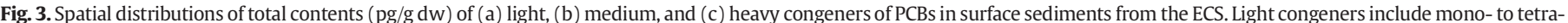
PCBs, medium congeners include penta- to hepta-PCBs, and heavy congeners include octa- to deca-PCBs.

respectively), followed by hepta-PCBs (17.5\%) in $\mathrm{PM}_{2.5}$ particles at Taizhou in the winter; the average content of $\sum_{38} \mathrm{PCBs}$ in $\mathrm{PM}_{2.5}$ in the winter was $1227 \pm 433 \mathrm{pg} / \mathrm{m}^{3}$ (Han et al., 2010). Compared with heavy PCBs, areas with high medium PCBs expanded more southeastward (Fig. $3 \mathrm{~b}$ and c), further suggesting that a large proportion of the sedimentary PCBs in this region may have originated from local atmospheric deposition other than YR (Zhou et al., 2012).

\subsection{Source identification of regional PCBs implied by biomaker-based proxies}

Multiple biomarker-based proxies have a good potential for evaluating TOM inputs and contributions on sedimentary OM in many ocean systems (Amo and Minagawa, 2003; Xing et al., 2011b; Zhao et al., 2000). In the ECS, TOM from YR are mainly preserved in the inner shelf from YR mouth to the Zhejiang-Fujian coastline (Xing et al., 2011b). The proxies of $\sum C_{27}+C_{29}+C_{31} n$-alkanes and TMBR have a potential for tracing the SCCP sources and migration paths in the YRE, as well as the inner shelf of ECS (Zhao et al., 2013b). Here, $\sum C_{27}+C_{29}+C_{31} n$-alkanes and BIT index were introduced to further identify the source differences of regional PCBs in the ECS.

$\sum C_{27}+C_{29}+C_{31} n$-alkanes (Fig. $4 a$ ) presented a clear spatial pattern with high values from YRE to the inner shelf along the coastline, a decreasing trend from the inshore to the offshore, and a relatively high value region in the mud area southwest of Cheju Island. These results are similar to those of $\sum_{24} \mathrm{PCBs}$ (Fig. 2a). Correlation analysis showed that $\sum_{24} \mathrm{PCBs}$ were positively correlated to the contents of $\sum \mathrm{C}_{27}+$ $C_{29}+C_{31} n$-alkanes $(r=0.686, p<0.05)$. The resemblance partly implied that a certain proportion of PCBs was from a similar source and has a similar migration path with those of the $C_{27}+C_{29}+C_{31} n$ alkanes, which are mainly from river input through YR and atmospheric deposition (Xing et al., 2011b). The distribution pattern of the BIT index (Fig. 4b) presented a seaward decreasing trend, with high values mainly located in the YRE and in the inner shelf north of $29^{\circ} \mathrm{N}$, indicating that 

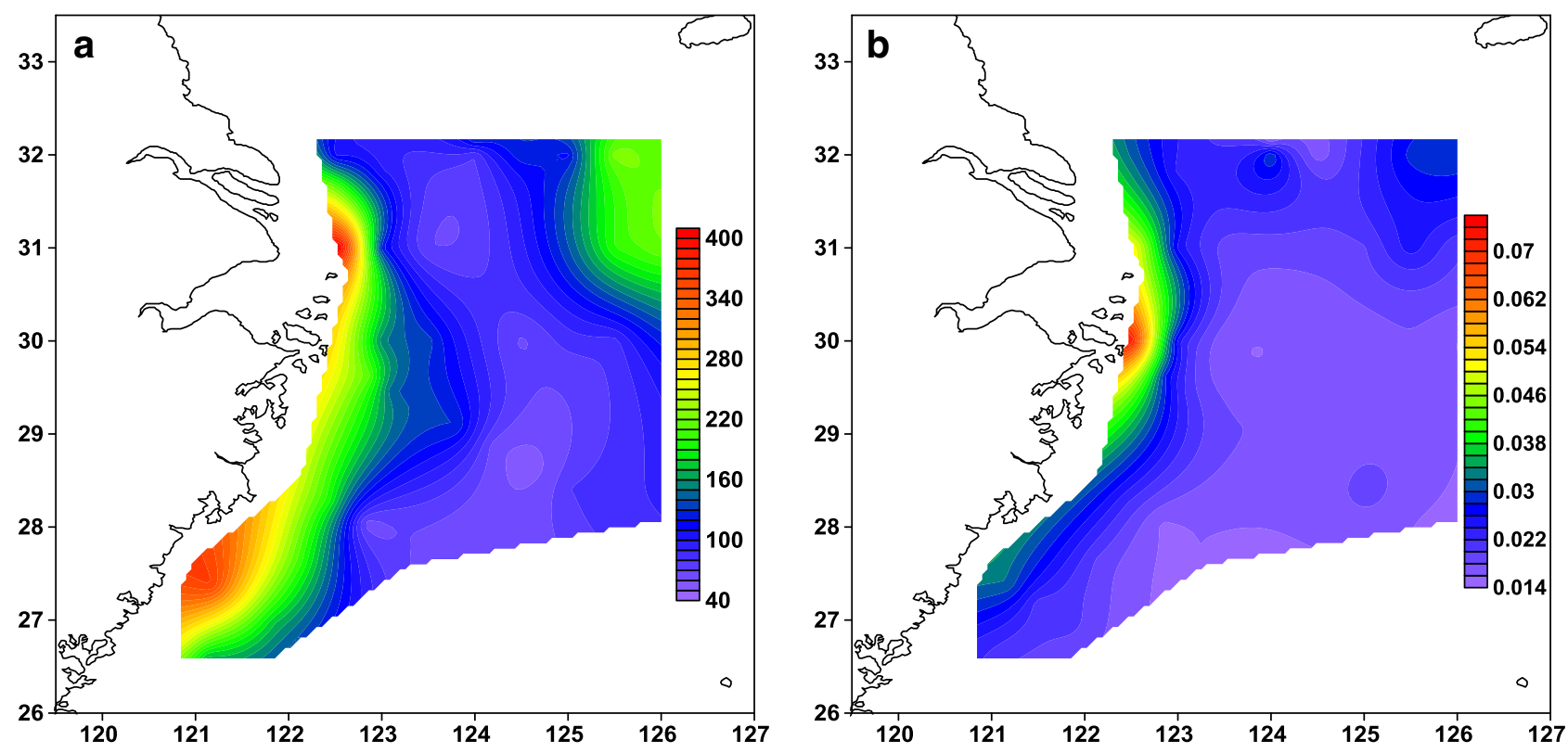

Fig. 4. Spatial distributions of contents of (a) $\sum C_{27}+C_{29}+C_{31} n$-alkanes (ng/g dw) and (b) BIT index in surface sediments from the ECS.

majority of the fluvial TOM from YR was deposited in this region (Liu et al., 2007). Compared with those of $\sum_{24} \mathrm{PCBs}$ and $\sum \mathrm{C}_{27}+\mathrm{C}_{29}+$ $\mathrm{C}_{31} n$-alkanes, no high values of BIT index were observed in the inner shelf south of the $29^{\circ} \mathrm{N}$ and at the center shelf southwest of Cheju Island. The correlation analysis showed that contents of $\sum_{24} \mathrm{PCBs}$ and BIT index were weakly correlated $(r=0.344, p<0.05)$.

Based on the geographical characteristic and congener compositions of PCBs and biomarkers, we concluded that various sources could contribute to sedimentary PCBs in the ECS. PCBs near YR mouth and in the inner shelf north of $29^{\circ} \mathrm{N}$ may be from both YR and atmospheric deposition. PCBs in the mud area southwest of the Cheju Island may originate from North China through atmospheric transport. PCBs in the inner shelf south of $29^{\circ} \mathrm{N}$ should be mainly attributed to the deposition of atmospheric PCBs from the Taizhou-Wenzhou region.

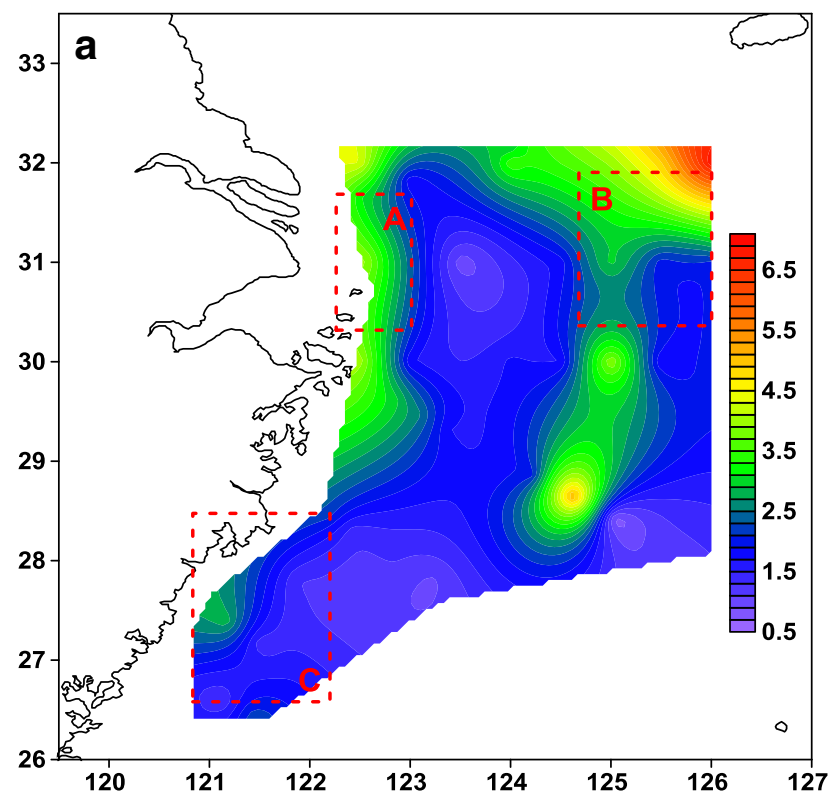

\subsection{Dechlorination behavior implicated by hypoxia and ladderane lipids}

Although PCBs are commonly considered to be stable and persistent, biodegradation of PCBs in the environment is inevitable. Aerobic oxidative degradation and anaerobic reductive dechlorination have been identified to be the two main microbial processes for PCB biodegradation (Abramowicz, 1990; Wiegel and Wu, 2000). The dechlorination process typically removes the meta- and para-chlorines (Abramowicz, 1990). With such structural characteristics, the dechlorination pathway of the parent compound PCB180 that degraded to PCB153, PCB101, and PCB52 under anaerobic conditions was inferred in a recent study (Payne et al., 2011). Here, we chose the ratios of PCB52/PCB180 (ratio I), PCB101/PCB180 (ratio II), and PCB153/PCB180 (ratio III) (Table S5) as the non-definitive indicators of the $\mathrm{PCB}$ reductive dechlorination

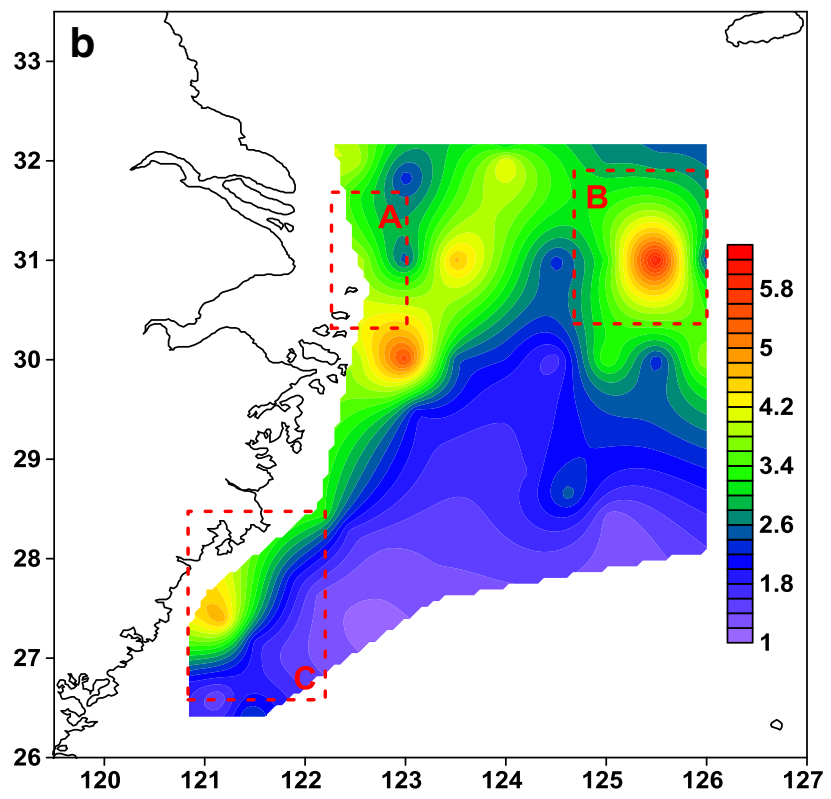

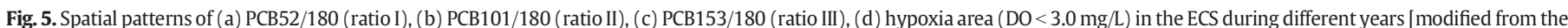

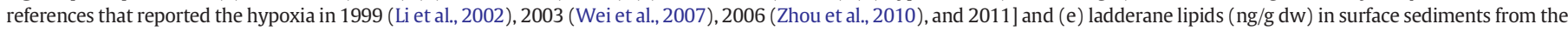

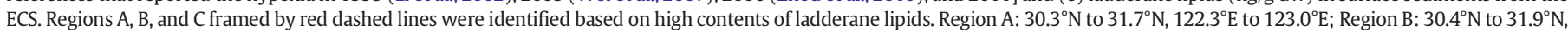
$124.7^{\circ} \mathrm{E}$ to $126.0^{\circ} \mathrm{E}$; Region C: $26.6^{\circ} \mathrm{N}$ to $28.5^{\circ} \mathrm{N}, 120.8^{\circ} \mathrm{E}$ to $122.2^{\circ} \mathrm{E}$. 

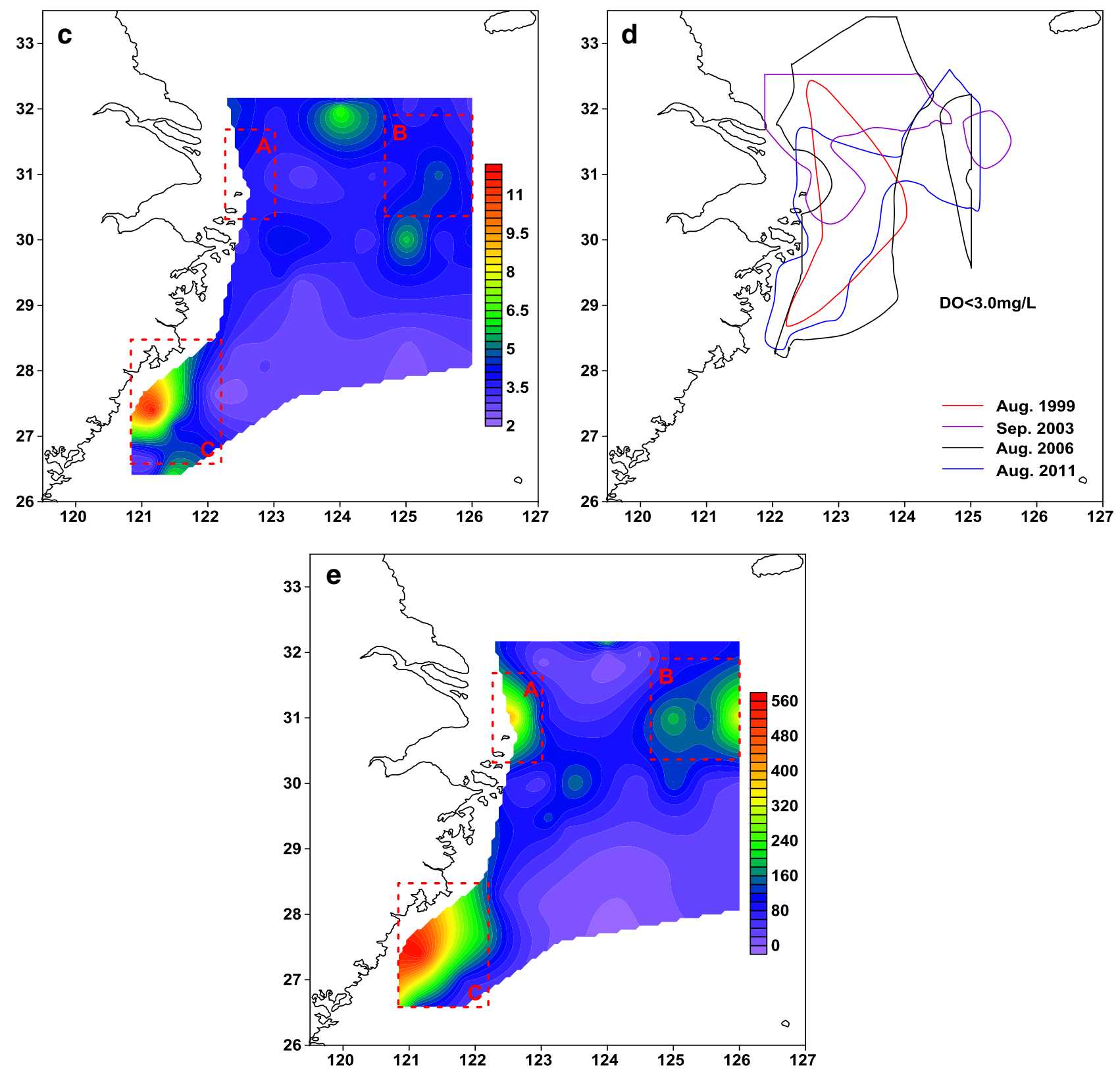

Fig. 5 (continued).

relationship. Spatial distributions of ratios I, II, and III in the surface sediments are shown in Fig. 5a to c, respectively. The results showed that high values of these ratios were mainly located in the vicinity of YRE, in the inner shelf along the coastline and in the ECS center shelf, indicating that the dechlorination of PCBs may be ubiquitous in these areas.

Recent studies have shown that the ECS is one of the largest coastal low-oxygen areas worldwide, and hypoxia near the YRE and adjacent areas presents a gradual increasing trend as a result of severe eutrophication and stratification especially during summer (Chen et al., 2007; Zhu et al., 2011). Microbial reductive dechlorination of PCBs can occur in soils and aquatic sediments under anaerobic conditions (Abraham et al., 2002; Abramowicz et al., 1993). Thus, hypoxic and anoxic environments in the ocean should favor this microbial process. Pooled bottom hypoxic zones in August 1999 (Li et al., 2002), September 2003 (Wei et al., 2007), August 2006 (Zhou et al., 2010), and August 2011 in the ECS are shown in Fig. 5d. The hypoxia on the bottom of ECS was mainly oriented along the coast near the YRE, extending from offshore to the center shelf. Comparing the spatial patterns of ratios I, II, and III with hypoxia showed that they broadly corresponded to each other, indicating the occurrence of deep dechlorination of PCBs in the hypoxia zone (Yang et al., 2012).

High $\sum$ ladderane lipids (four kinds of ladderane fatty acid methyl esters, Fig. S2 and Table S4) were found at region A (near the YRE, $30.3^{\circ} \mathrm{N}$ to $31.7^{\circ} \mathrm{N}, 122.3^{\circ} \mathrm{E}$ to $123.0^{\circ} \mathrm{E}$ ), region $\mathrm{B}$ (southwest of Cheju Island, $30.4^{\circ} \mathrm{N}$ to $31.9^{\circ} \mathrm{N}, 124.7^{\circ} \mathrm{E}$ to $126.0^{\circ} \mathrm{E}$ ), and region $\mathrm{C}$ (southwest of the investigated area, $26.6^{\circ} \mathrm{N}$ to $28.5^{\circ} \mathrm{N}, 120.8^{\circ} \mathrm{E}$ to $122.2^{\circ} \mathrm{E}$ ), suggesting the intensified anammox activities and low levels of dissolved oxygen in these three regions (Fig. 5e) (Jaeschke et al., 2009b; Zhao et al., 2013a). Overall, areas with high-values of ladderane lipids also broadly corresponded to those of the three ratios, despite the occurrence of high ratio III (Fig. 5c) only in region C. A significant positive relationship was also observed between the $\sum$ ladderane lipids and ratios of PCB153/PCB180 $(r=0.511, p<0.05)$ in surface sediments from the ECS. These results further implied that the deep dechlorination of PCBs mainly occurred in the hypoxia zone, which are preferred by anaerobic microorganisms. Furthermore, a recent study has reported that 
abundant anammox bacteria were found in the YRE sediments (Hou et al., 2013), suggesting that anaerobic dechlorination of PCBs from river input by YR also occurs during their transportation.

\section{Conclusion}

The surface sedimentary PCBs in the ECS generally revealed a seaward decreasing trend and a north-south increasing trend along the coastline, dominated by light congeners. Regional sources of PCBs in surface sediments from the ECS were substantially different, and are described as follows: (1) PCBs near YR mouth and in the inner shelf north of $29^{\circ} \mathrm{N}$ should be from both the YR inputs and atmospheric deposition; (2) PCBs in the center shelf southwest off the Cheju Island should originate from North China through atmospheric transport and deposition mediated by biological pump; and (3) PCBs in the inner shelf south of $29^{\circ} \mathrm{N}$ should be mainly attributed to the deposition of gas-phase PCBs from the Taizhou-Wenzhou region. Anaerobic biodegradation of PCBs mainly occurred in the Zhejiang-Fujian coastal area and center shelf southwest off the Cheju Island of the ECS. This study provides a novel methodology for studying the sources, migration, and behavior of POPs in marine environment, and then for further evaluating their ecological risk. However, the validity in different sea regions still needs to be evaluated.

\section{Conflict of interest} work.

The authors declare that they have no conflicts of interest to this

\section{Acknowledgments}

This study was supported by the National Basic Research Program of China (973 Program 2010CB428901), the National Natural Science Foundation of China (21007062 and 41221004), the Young Teachers Special Fund, Ocean University of China (No. 201013018) and the SOA Open Fund (MESE-2011-07). We want to thank Hailong Zhang and Li Li for technical assistance, and the crew of R/V of Beidou of the Yellow Sea Fisheries Research Institute for helping to obtain the sediment samples. This is MCTL contribution no. 36.

\section{Appendix A. Supplementary data}

Introduction to TOC analysis, PCB compositions in the surface sediments from the ECS (Fig. S1), average concentrations of individual PCB analogs detected in the blank samples (Table S1), average recoveries of individual ${ }^{13} \mathrm{C}$-labeled PCB analogs (Table S2), individual concentrations of PCBs in surface sediment from the ECS (Table S3), contents of $\sum_{24}$ PCBs, TOC, BIT index, $\sum C_{27}+C_{29}+C_{31} n$-alkanes and $\sum$ ladderane lipids in surface sediments (Table S4), values of ratio I, ratio II and ratio III in surface sediments from the ECS (Table S5), and molecular structures of ladderane lipids (Fig. S2) are shown in the supplementary content. Supplementary data to this article can be found online at http://dx.doi.org/10.1016/j.scitotenv.2014.05.054.

\section{References}

Abraham W-R, Nogales B, Golyshin PN, Pieper DH, Timmis KN. Polychlorinated biphenyldegrading microbial communities in soils and sediments. Curr Opin Microbiol 2002; 5:246-53.

Abramowicz DA. Aerobic and anaerobic biodegradation of PCBs: a review. Crit Rev Biotechnol 1990;10:241-51.

Abramowicz DA, Brennan MJ, Van Dort HM, Gallagher EL. Factors influencing the rate of polychlorinated biphenyls dechlorination in Hudson River sediments. Environ Sci Technol 1993;27:1125-31.

Amo M, Minagawa M. Sedimentary record of marine and terrigenous organic matter delivery to the Shatsky Rise, western North Pacific, over the last 130 kyr. Org Geochem 2003;34:1299-312.
Arzayus KM, Dickhut RM, Canuel EA. Fate of atmospherically deposited polycyclic aromatic hydrocarbons (PAHs) in Chesapeake Bay. Environ Sci Technol 2001;35:2178-83.

Bird MI, Summons RE, Gagan MK, Roksandic Z, Dowling L, Head J, et al. Terrestrial vegetation change inferred from n-alkane $\sigma^{13} \mathrm{C}$ analysis in the marine environment. Geochim Cosmochim Acta 1995;59:2853-7.

Chen S-J, Gao X-J, Mai B-X, Chen Z-M, Luo X-J, Sheng G-Y, et al. Polybrominated diphenyl ethers in surface sediments of the Yangtze River Delta: levels, distribution and potential hydrodynamic influence. Environ Pollut 2006;144:951-7.

Chen C-C, Gong G-C, Shiah F-K. Hypoxia in the East China Sea: one of the largest coastal low-oxygen areas in the world. Mar Environ Res 2007;64:399-408.

Dachs J, Bayona JM, Ittekkot V, Albaigés J. Monsoon-driven vertical fluxes of organic pollutants in the Western Arabian Sea. Environ Sci Technol 1999;33:3949-56.

Dachs J, Eisenreich SJ, Hoff RM. Influence of eutrophication on air-water exchange, vertical fluxes, and phytoplankton concentrations of persistent organic pollutants. Environ Sci Technol 2000;34:1095-102.

Dachs J, Lohmann R, Ockenden WA, Méjanelle L, Eisenreich SJ, Jones KC. Oceanic biogeochemical controls on global dynamics of persistent organic pollutants. Environ Sci Technol 2002;36:4229-37.

Dahle S, Savinov VM, Matishov GG, Evenset A, Næs K. Polycyclic aromatic hydrocarbons (PAHs) in bottom sediments of the Kara Sea shelf, Gulf of Ob and Yenisei Bay. Sci Total Environ 2003;306:57-71.

DeMaster DJ, McKee BA, Nittrouer CA, Jiangchu Q, Guodong C. Rates of sediment accumulation and particle reworking based on radiochemical measurements from continental shelf deposits in the East China Sea. Cont Shelf Res 1985;4:143-58.

Duan X, Li Y, Li X, Li M, Zhang D. Distributions and sources of polychlorinated biphenyls in the coastal East China Sea sediments. Sci Total Environ 2013;463-464:894-903.

Fowler SW. Critical review of selected heavy metal and chlorinated hydrocarbon concentrations in the marine environment. Mar Environ Res 1990;29:1-64.

Fu J, Mai B, Sheng G, Zhang G, Wang X, Peng Pa, et al. Persistent organic pollutants in environment of the Pearl River Delta, China: an overview. Chemosphere 2003;52:1411-22.

Gagosian RB, Peltzer ET, Zafiriou OC. Atmospheric transport of continentally derived lipids to the tropical North Pacific. Nature 1981;291:312-4.

Galbán-Malagón C, Berrojalbiz N, Ojeda M-J, Dachs J. The oceanic biological pump modulates the atmospheric transport of persistent organic pollutants to the Arctic. Nat Commun 2012;3:862.

Gao S, Chen J, Shen Z, Liu H, Chen Y. Seasonal and spatial distributions and possible sources of polychlorinated biphenyls in surface sediments of Yangtze Estuary, China. Chemosphere 2013;91:809-16.

Guo ZG, Yang ZS, Chen ZL, Mao D. Source of sedimentary organic matter in the mud areas of the East China Sea shelf. Geochimica 2001;30:416-24. [in Chinese].

Guo ZG, Sheng LF, Feng JL, Fang M. Seasonal variation of solvent extractable organic compounds in the aerosols in Qingdao, China. Atmos Environ 2003;37:1825-34.

Guo Z, Lin T, Zhang G, Yang Z, Fang M. High-resolution depositional records of polycyclic aromatic hydrocarbons in the central continental shelf mud of the East China Sea. Environ Sci Technol 2006;40:5304-11.

Han W, Feng J, Gu Z, Wu M, Sheng G, Fu J. Polychlorinated biphenyls in the atmosphere of Taizhou, a major e-waste dismantling area in China. J Environ Sci 2010;22:589-97.

Hedges JI, Keil RG. Sedimentary organic matter preservation: an assessment and speculative synthesis. Mar Chem 1995;49:81-115.

Hopmans EC, Weijers JWH, Schefuß E, Herfort L, Sinninghe Damsté JS, Schouten S. A novel proxy for terrestrial organic matter in sediments based on branched and isoprenoid tetraether lipids. Earth Planet Sci Lett 2004;224:107-16.

Hou L, Zheng Y, Liu M, Gong J, Zhang X, Yin G, et al. Anaerobic ammonium oxidation (anammox) bacterial diversity, abundance, and activity in marsh sediments of the Yangtze Estuary. J Geophys Res Biogeosci 2013;118:1237-46.

Hung C-C, Gong G-C, Ko F-C, Lee H-J, Chen H-Y, Wu J-M, et al. Polycyclic aromatic hydrocarbons in surface sediments of the East China Sea and their relationship with carbonaceous materials. Mar Pollut Bull 2011;63:464-70.

Jaeschke A, Hopmans EC, Wakeham SG, Schouten S, Sinninghe Damsté JS. The presence of ladderane lipids in the oxygen minimum zone of the Arabian Sea indicates nitrogen loss through anammox. Limnol Oceanogr 2007;52:780-6.

Jaeschke A, Rooks C, Trimmer M, Nicholls JC, Hopmans EC, Schouten S, et al. Comparison of ladderane phospholipid and core lipids as indicators for anaerobic ammonium oxidation (anammox) in marine sediments. Geochim Cosmochim Acta 2009a:73:2077-88.

Jaeschke A, Ziegler M, Hopmans EC, Reichart G-J, Lourens LJ, Schouten S, et al. Molecular fossil evidence for anaerobic ammonium oxidation in the Arabian Sea over the last glacial cycle. Paleoceanography 2009b;24. [PA2202].

Jones KC, de Voogt P. Persistent organic pollutants (POPs): state of the science. Environ Pollut 1999;100:209-21.

Jönsson A, Gustafsson Ö, Axelman J, Sundberg H. Global accounting of PCBs in the continental shelf sediments. Environ Sci Technol 2003;37:245-55.

Kim D, Choi SH, Kim KH, Shim J, Yoo S, Kim CH. Spatial and temporal variations in nutrient and chlorophyll-a concentrations in the northern East China Sea surrounding Cheju Island. Cont Shelf Res 2009;29:1426-36.

Kuypers MMM, Sliekers AO, Lavik G, Schmid M, Jorgensen BB, Kuenen JG, et al. Anaerobic ammonium oxidation by anammox bacteria in the Black Sea. Nature 2003;422: 608-11.

Li D, Zhang J, Huang D, Wu Y, Liang J. Oxygen depletion off the Changjiang (Yangtze River) Estuary. Sci China Ser D Earth Sci 2002;45:1137-46.

Lin S, Hsieh IJ, Huang K-M, Wang C-H. Influence of the Yangtze River and grain size on the spatial variations of heavy metals and organic carbon in the East China Sea continental shelf sediments. Chem Geol 2002;182:377-94.

Lin T, Hu L, Shi X, Li Y, Guo Z, Zhang G. Distribution and sources of organochlorine pesticides in sediments of the coastal East China Sea. Mar Pollut Bull 2012;64:1549-55.

Liu JP, Xu KH, Li AC, Milliman JD, Velozzi DM, Xiao SB, et al. Flux and fate of Yangtze River sediment delivered to the East China Sea. Geomorphology 2007;85:208-24. 
Lü X, Zhai S. Sources and transport of hydrocarbons in sediments from the Changjiang River Estuary, China. Mar Pollut Bull 2005;50:1738-44.

Mai B-X, Fu J-M, Sheng G-Y, Kang Y-H, Lin Z, Zhang G, et al. Chlorinated and polycyclic aromatic hydrocarbons in riverine and estuarine sediments from Pearl River Delta, China. Environ Pollut 2002;117:457-74.

Maruya KA, Risebrough RW, Horne AJ. Partitioning of polynuclear aromatic hydrocarbons between sediments from San Francisco Bay and their porewaters. Environ Sci Technol 1996;30:2942-7.

Milliman JD, Qin Y, Park YA. Sediments and sedimentary processes in the Yellow and East China Seas. Sedimentary facies in the active plate margin. Tokyo: Terra Scientific Publishing Company; 1989. p. 233-49.

Nie X, Lan C, Wei T, Yufeng Y. Distribution of polychlorinated biphenyls in the water sediment and fish from the Pearl River estuary, China. Mar Pollut Bull 2005;50: 537-46.

Payne RB, May HD, Sowers KR. Enhanced reductive dechlorination of polychlorinated biphenyl impacted sediment by bioaugmentation with a dehalorespiring bacterium. Environ Sci Technol 2011;45:8772-9.

Piérard C, Budzinski H, Garrigues P. Grain-size distribution of polychlorobiphenyls in coastal sediments. Environ Sci Technol 1996;30:2776-83.

Safe S. Toxicology, structure-function relationship, and human and environmental health impacts of polychlorinated biphenyls: progress and problems. Environ Health Perspect 1993;100:259-68.

Salau JSi, Tauler R, Bayona JM, Tolosa I. Input characterization of sedimentary organic contaminants and molecular markers in the Northwestern Mediterranean Sea by exploratory data analysis. Environ Sci Technol 1997;31:3482-90.

Simoneit BRT, Chester R, Eglinton G. Biogenic lipids in particulates from the lower atmosphere over the eastern Atlantic. Nature 1977;267:682-5.

Sinninghe Damsté JS, Schouten S, Hopmans EC, van Duin ACT, Geenevasen JAJ. Crenarchaeol: the characteristic core glycerol dibiphytanyl glycerol tetraether membrane lipid of cosmopolitan pelagic crenarchaeota. J Lipid Res 2002;43:1641-51.

Wafo E, Sarrazin L, Diana C, Schembri T, Lagadec V, Monod J-L. Polychlorinated biphenyls and DDT residues distribution in sediments of Cortiou (Marseille, France). Mar Pollut Bull 2006;52:104-7.

Wang X-C, Sun M-Y, Li A-C. Contrasting chemical and isotopic compositions of organic matter in Changjiang (Yangtze River) estuarine and East China Sea shelf sediments. J Oceanogr 2008;64:311-21.

Wei H, He Y, Li Q Liu Z, Wang H. Summer hypoxia adjacent to the Changjiang Estuary. J Mar Syst 2007;67:292-303.

Wiegel J, Wu Q. Microbial reductive dehalogenation of polychlorinated biphenyls. FEMS Microbiol Ecol 2000;32:1-15.

Wilkening KE, Barrie LA, Engle M. Trans-Pacific air pollution. Science 2000;290:65-7.

Wong MH, Wu SC, Deng WJ, Yu XZ, Luo Q Leung AOW, et al. Export of toxic chemicals-a review of the case of uncontrolled electronic-waste recycling. Environ Pollut 2007; 149:131-40.

Wu Y, Zhang J, Li DJ, Wei H, Lu RX. Isotope variability of particulate organic matter at the PN section in the East China Sea. Biogeochemistry 2003;65:31-49.
Xiao S, Li A, Jiang F, You Z, Chen L. Provenance analysis of mud along the Min-Zhe coast since 2 ka BP. Acta Sedimentol Sin 2005;23:268-74. [in Chinese].

Xing L, Tao S, Zhang H, Liu Y, Yu Z, Zhao M. Distributions and origins of lipid biomarkers in surface sediments from the southern Yellow Sea. Appl Geochem 2011a;26:1584-93.

Xing L, Zhang H, Yuan Z, Sun Y, Zhao M. Terrestrial and marine biomarker estimates of organic matter sources and distributions in surface sediments from the East China Sea shelf. Cont Shelf Res 2011b;31:1106-15.

Yang R-q, Jiang G-b, Zhou Q-f, Yuan C-g, Shi J-b. Occurrence and distribution of organochlorine pesticides (HCH and DDT) in sediments collected from East China Sea. Environ Int 2005;31:799-804.

Yang H, Xue B, Jin L, Zhou S, Liu W. Polychlorinated biphenyls in surface sediments of Yueqing Bay, Xiangshan Bay, and Sanmen Bay in East China Sea. Chemosphere 2011;83:137-43.

Yang H, Zhuo S, Xue B, Zhang C, Liu W. Distribution, historical trends and inventories of polychlorinated biphenyls in sediments from Yangtze River Estuary and adjacent East China Sea. Environ Pollut 2012;169:20-6.

Zeng L, Zhao Z, Li H, Wang T, Liu Q Xiao K, et al. Distribution of short chain chlorinated paraffins in marine sediments of the East China Sea: influencing factors, transport and implications. Environ Sci Technol 2012;46:9898-906.

Zhang J, Huang WW, Liu SM, Liu MG, Yu Q, Wang JH. Transport of particulate heavy metals towards the China Sea: a preliminary study and comparison. Mar Chem 1992;40:161-78.

Zhang P, Song J, Liu Z, Zheng G, Zhang N, He Z. PCBs and its coupling with ecoenvironments in Southern Yellow Sea surface sediments. Mar Pollut Bull 2007;54: 1105-15.

Zhao M, Eglinton G, Haslett SK, Jordan RW, Sarnthein M, Zhang Z. Marine and terrestrial biomarker records for the last 35,000 years at ODP site 658C off NW Africa. Org Geochem 2000;31:919-30.

Zhao L, Hou H, Zhou Y, Xue N, Li H, Li F. Distribution and ecological risk of polychlorinated biphenyls and organochlorine pesticides in surficial sediments from Haihe River and Haihe Estuary Area, China. Chemosphere 2010;78:1285-93.

Zhao Z, Cao Y, Li L, Song G, Yang H, Liu S, et al. Sedimentary ladderane core lipids as potential indicators of hypoxia in the East China Sea. Chinese J Oceanol Limnol 2013a; 31:237-44.

Zhao Z, Li H, Wang Y, Li G, Cao Y, Zeng L, et al. Source and migration of short-chain chlorinated paraffins in the Coastal East China Sea using multiproxies of marine organic geochemistry. Environ Sci Technol 2013b;47:5013-22.

Zhou F, Huang D, Ni X, Xuan J, Zhang J, Zhu K. Hydrographic analysis on the multi-time scale variability of hypoxia adjacent to the Changjiang River Estuary. Acta Ecol Sin 2010;30:4728-40. [in Chinese].

Zhou S-s, Shao L-y, Yang H-y, Wang C, Liu W-p. Residues and sources recognition of polychlorinated biphenyls in surface sediments of Jiaojiang Estuary, East China Sea. Mar Pollut Bull 2012;64:539-45.

Zhu Z-Y, Zhang J, Wu Y, Zhang Y-Y, Lin J, Liu S-M. Hypoxia off the Changjiang (Yangtze River) Estuary: oxygen depletion and organic matter decomposition. Mar Chem 2011;125:108-16. 